\title{
The CCAAT/enhancer binding protein (C/EBP) $\delta$ is differently regulated by fibrillar and oligomeric forms of the Alzheimer amyloid- $\beta$ peptide
}

\author{
Veronica Ramberg ${ }^{1}$, Linda M Tracy ${ }^{1}$, Malin Samuelsson', Lars NG Nilsson² and Kerstin Iverfeldt ${ }^{\text {* }}$
}

\begin{abstract}
Background: The transcription factors CCAAT/enhancer binding proteins (C/EBP) $\alpha, \beta$ and $\delta$ have been shown to be expressed in brain and to be involved in regulation of inflammatory genes in concert with nuclear factor $\kappa \mathrm{B}$ (NF- $\kappa \mathrm{B})$. In general, C/EBP $\alpha$ is down-regulated, whereas both C/EBP $\beta$ and $\delta$ are up-regulated in response to inflammatory stimuli. In Alzheimer's disease (AD) one of the hallmarks is chronic neuroinflammation mediated by astrocytes and microglial cells, most likely induced by the formation of amyloid- $\beta$ ( $A \beta$ ) deposits. The inflammatory response in $A D$ has been ascribed both beneficial and detrimental roles. It is therefore important to delineate the inflammatory mediators and signaling pathways affected by $A \beta$ deposits with the aim of defining new therapeutic targets.
\end{abstract}

Methods: Here we have investigated the effects of $A \beta$ on expression of C/EBP family members with a focus on C/EBP $\delta$ in rat primary astro-microglial cultures and in a transgenic mouse model with high levels of fibrillar $A \beta$ deposits (tg-ArcSwe) by western blot analysis. Effects on DNA binding activity were analyzed by electrophoretic mobility shift assay. Cross-talk between C/EBP $\delta$ and NF- $\kappa$ B was investigated by analyzing binding to a $\kappa \mathrm{B}$ site using a biotin streptavidin-agarose pull-down assay.

Results: We show that exposure to fibril-enriched, but not oligomer-enriched, preparations of A $\beta$ inhibit upregulation of C/EBP $\delta$ expression in interleukin-1 $\beta$-activated glial cultures. Furthermore, we observed that, in aged transgenic mice, C/EBP $\alpha$ was significantly down-regulated and C/EBP $\beta$ was significantly up-regulated. C/EBP $\delta$, on the other hand, was selectively down-regulated in the forebrain, a part of the brain showing high levels of fibrillar $A \beta$ deposits. In contrast, no difference in expression levels of C/EBP $\delta$ between wild type and transgenic mice was detected in the relatively spared hindbrain. Finally, we show that interleukin-1 $\beta$-induced C/EBP $\delta$ DNA binding activity to both $C / E B P$ and $\kappa B$ sites is abolished after exposure to $A \beta$.

Conclusions: These data suggest that both expression and function of C/EBP $\delta$ are dysregulated in Alzheimer's disease. C/EBP $\delta$ seems to be differently regulated in response to different conformations of $A \beta$. We propose that $A \beta$ induces an imbalance between NF- $\kappa$ B and C/EBP transcription factors that may result in abnormal responses to inflammatory stimuli.

\section{Background}

Alzheimer's disease (AD) is a neurodegenerative disorder and is the most common cause of dementia among the elderly. Accumulation of amyloid- $\beta$ (A $\beta)$ peptides in the brain is considered to be a key step in the pathogenesis of the disease and leads to formation of amyloid

\footnotetext{
* Correspondence: kerstin@neurochem.su.se

'Department of Neurochemistry, Stockholm University, SE-10691 Stockholm; Sweden

Full list of author information is available at the end of the article
}

plaques in brain parenchyma. The $A \beta$ peptides can be truncated at both the $\mathrm{C}$ - and $\mathrm{N}$-terminal ends, and also undergo posttranslational modifications. Although $A \beta 1$ 40 (40 amino acids long) is the most abundant form, the major focus is on $A \beta 1-42$ which is more prone to aggregate and considered to be the most neurotoxic form. $A \beta$ is found in different aggregation states in the brain ranging from monomers and non-fibrillar aggregates, termed oligomers, to a highly fibrillar form found in the deposits. Recent evidence suggests that diffusible

\section{Biomed Central}


$\mathrm{A} \beta$ oligomers have the most toxic properties [1,2]. However, it should also be noted that $A \beta$ fibril-containing senile plaques precede the development of dystrophic neurites [3] and of spinodendritic calcium decompartmentalization that presumably leads to cognitive dysfunction [4]. In addition to massive neurodegeneration, chronic neuroinflammation is a pathological hallmark of $\mathrm{AD}$, manifested by activated microglia and reactive astrocytes. Accumulation and deposition of $\mathrm{A} \beta$ can trigger activation of glial cells, which will set off an inflammatory response that, over time, becomes chronic causing a persistent deleterious condition [5].

The role of neuroinflammation in the development and progression of $\mathrm{AD}$ is, however, not clear. Neuroinflammation is often referred to as a "double-edged sword". On the one hand microglia and astrocytes secrete inflammatory cytokines, chemokines and neurotoxins upon activation, and can thereby promote neuronal degeneration. On the other hand, activated microglia surrounding $A \beta$ plaques may have beneficial effects by phagocytosis of, and thus elimination of, $A \beta$ [6]. Astrocytes have also been reported to be able to migrate towards $A \beta$ plaques and, upon contact, to degrade $A \beta$ $[7,8]$. This somewhat confusing picture calls for delineation of signaling pathways that may be involved in the beneficial effects of neuroinflammation or that may promote neurodegeneration.

The inflammatory response is, to a large degree, orchestrated by the transcription factor nuclear factor $\kappa \mathrm{B}$ (NF$\kappa \mathrm{B})$. However, NF- $\kappa \mathrm{B}$ works in concert with other transcription factors. Of particular interest are members of the CCAAT/enhancer binding protein (C/EBP) family that can amplify the effects of NF- $\kappa \mathrm{B}$ and may also form heteromeric complexes with NF- $\kappa \mathrm{B}[9-11]$. C/EBP is a protein family consisting of six members, $\mathrm{C} / \mathrm{EBP} \alpha-\zeta$ (reviewed in [12]). In order to be active, C/EBPs will form homo- or heterodimers with each other or with other transcription factors. Until recently, C/EBP studies have mainly focused on the liver, where these proteins regulate expression of a variety of genes including acute phase proteins [13]. However, $\mathrm{C} / \mathrm{EBP} \alpha, \beta$ and $\delta$ are also all expressed in brain $[14,15]$. Among their target genes are many pro-inflammatory cytokines including interleukin- (IL-) 6 (an early inflammatory marker in AD brain), inducible nitric oxide synthase, complement factors, and cyclooxygenase-2 (COX-2) [16]. In both brain and liver, inflammatory stimuli have been shown to, in general, down-regulate expression of $\mathrm{C} / \mathrm{EBP} \alpha$ and up-regulate expression of C/EBP $\beta$ and $\delta$ [15]. Several previous studies have suggested that members of the C/EBP transcription factor family are dysregulated in $\mathrm{AD}$ and in response to $\mathrm{A} \beta$. mRNA levels of $\mathrm{C} / \mathrm{EBP} \alpha, \beta$ and $\delta$ have all been shown to be up-regulated in hippocampus of AD patients [17-19] and protein levels of $\mathrm{C} / \mathrm{EBP} \delta$ have also been reported to be up-regulated in AD brain [20]. However, in a recent study we observed that $\mathrm{C} / \mathrm{EBP} \delta$ DNA binding activity to a C/EBP motif is, instead, completely blocked in IL- $1 \beta$-stimulated primary astro-microglial cultures from rats after exposure to oligomeric forms of $A \beta$ peptides [21]. It can be speculated that $A \beta$ peptides cause an imbalance between NF- $\kappa \mathrm{B}$ and $\mathrm{C} / \mathrm{EBP}$ transcription factors that could result in abnormal responses to inflammatory stimuli. To further investigate how the inflammatory response in the AD brain may be affected we have analyzed the effects of different aggregation states of $\mathrm{A} \beta$ on NF- $\kappa \mathrm{B}-\mathrm{C} / \mathrm{EBP}$ cross-talk, and also $\mathrm{C} /$ $\mathrm{EBP} \alpha$ and $\delta$ expression levels in activated primary glial cultures. In addition, we have analyzed the expression levels of $\mathrm{C} / \mathrm{EBP} \alpha, \beta$ and $\delta$ and in mice with high levels of fibrillar $A \beta$ deposits.

\section{Methods}

\section{Primary astro-microglial cultures and treatments}

Primary mixed glial cultures consisting of 5-10\% microglia and $90-95 \%$ astrocytes (hereafter referred to as astro-microglial cultures) were obtained from male Sprague Dawley pups less than 24 h of age as previously described [22]. The experimental procedures were approved by Stockholm North Local Committee on Ethics of Animal Experiments and performed in accordance with international standards on animal welfare. Cells were seeded in $60 \mathrm{~mm}$ culture dishes and maintained in DMEM glutamax containing 10\% fetal bovine serum (FBS) and $0.1 \%$ penicillin-streptomycin (PEST) for 20-22 days (all from GIBCO). Medium was exchanged every 3-4 day. $18 \mathrm{~h}$ prior to experiment, medium was exchanged to DMEM glutamax containing $0.2 \%$ FBS and $0.1 \%$ PEST. Confluent cells were exposed to $10 \mu \mathrm{M} A \beta(1-42), 10 \mu \mathrm{M} A \beta(42-1)$ (American peptide), $10 \mathrm{ng} / \mathrm{ml}$ rat recombinant IL-1 $\beta$ (Biosource) and/ or $1 \mu \mathrm{g} / \mathrm{ml}$ lipopolysaccharide (LPS, Sigma) for $3 \mathrm{~h}$ before analysis. A $\beta$ preparations enriched in oligomeric or fibrillar forms were prepared as previously described $[23,24]$. Briefly, $A \beta$ was dissolved in hexafluoroisopropanol (HFIP) to a final concentration of $1 \mathrm{mM}$. HFIP was then removed by centrifugation under vacuum, and $A \beta$ was then resuspended in dimethyl sulfoxide (DMSO, Sigma) to a final concentration of $5 \mathrm{mM}$. To obtain oligomers, culture medium was added to the peptide to a final concentration of $100 \mu \mathrm{M}$ followed by an incubation at $4^{\circ} \mathrm{C}$ for $24 \mathrm{~h}$. For a fibril-enriched preparation, $10 \mathrm{mM} \mathrm{HCl}$ was added to the peptide to a final concentration of $100 \mu \mathrm{M}$, followed by incubation for $24 \mathrm{~h}$ at $37^{\circ} \mathrm{C}$. The different $\mathrm{A} \beta$ preparations were analyzed using western blot (see western blot) and Thioflavin $\mathrm{T}$ assay (T3516, Sigma). In the Thioflavin $\mathrm{T}$ assay, $\mathrm{A} \beta$ samples were analyzed in phenol red-free medium and according to the manufacturer's instructions. 


\section{Nuclear extracts}

Nuclear extracts were prepared as follows: cells were washed in ice-cold PBS, scraped and subsequently centrifuged for $2 \mathrm{~min}$. Thereafter the pellet was washed again in PBS, centrifuged for $25 \mathrm{~s}$ and resuspended in $\mathrm{HB}$ buffer $(10 \mathrm{mM}$ Tris $\mathrm{HCl} \mathrm{pH} \mathrm{7.4,} 10 \mathrm{mM} \mathrm{KCl,} 1.5$ $\mathrm{mM} \mathrm{MgCl}_{2}, 0.5 \mathrm{mM}$ PMSF, $0.5 \mathrm{mM} \beta$-mercaptoetha$\mathrm{nol}$ ), centrifuged for $25 \mathrm{~s}$ and resuspended in lysis buffer (HB buffer, 0.4\% Nonidet-40). Samples were then lysed on ice for $10 \mathrm{~min}$. Nuclear fractions were pelleted by centrifugation for $5 \mathrm{~min}$, and then resuspended in buffer C (10 mM HEPES pH 7.9, 0.4 M NaCl, 1 mM EDTA, 1 mM DTT, $1 \mathrm{mM}$ PMSF) and thereafter placed on a shaking platform for $30 \mathrm{~min}$ and centrifuged for $5 \mathrm{~min}$. The supernatant containing nuclear extract was collected and stored at $-80^{\circ} \mathrm{C}$ for approximately $24 \mathrm{~h}$ before use. All steps were performed at $4^{\circ} \mathrm{C}$ and all centrifugations were performed at $16,000 \mathrm{~g}$.

\section{Transgenic mice}

Transgenic mice, tg-ArcSwe, carrying both the Artic (E693G) and the Swedish (KM670/671NL) APP double mutations were originally of $\mathrm{C} 57 \mathrm{Bl} / 6-\mathrm{CBA}-\mathrm{F} 1$ background [25], but then bred on a $\mathrm{C} 57 \mathrm{Bl} / 6$ background for more than six generations (incipient congenics). The experiments were approved by an ethical committee (Uppsala djurförsöksetiska nämnd) and performed in compliance with national and local animal care and use guidelines (protocol \#C223/8). Animals were 15.5-17 month of age when sacrificed. At this age tg-ArcSwe mice have previously been shown to possess a plaque burden of approximately $4 \%$, as measured by $\mathrm{A} \beta$ immunostaining of tissue sections followed by quantitative image analysis [26,27]. Mice were anesthetized with $0.3 \mathrm{ml}$ Avertin $(25 \mathrm{mg} / \mathrm{ml})$ and intracardially perfused with $0.9 \%$ saline solution. The brains were removed and dissected into amyloid-containing forebrain (including cortex and hippocampus) and amyloid-sparse hindbrain (cerebellum and brainstem) (cf. [25]). After dissection the samples were snap-frozen and stored in liquid nitrogen until use. As a control for changes related to age and $\mathrm{A} \beta$ deposition in the animals, 4 monthold tg-ArcSwe and non-transgenic animals were also investigated. Protein lysates were prepared as follows: forebrain and hindbrain were homogenized in ice-cold RIPA buffer (50 mM Tris $\mathrm{HCl} \mathrm{pH} \mathrm{8,} 150 \mathrm{mM} \mathrm{NaCl}, 1 \%$ Nonidet-40, $0.5 \%$ sodium deoxycholate, $1 \%$ SDS, $1 \mathrm{mM}$ PMSF) to a concentration of $25 \mathrm{mg} / \mathrm{ml}$ and placed on a shaking platform for $5 \mathrm{~h}$ at $4^{\circ} \mathrm{C}$. Thereafter the samples were centrifuged for $20 \mathrm{~min}$ at 9,500 $\mathrm{g}$ and the protein containing supernatant was collected and stored at $-80^{\circ} \mathrm{C}$ until used.

\section{A $\beta$ ELISA}

For measurement of total $A \beta$ levels, ninety-six-well plates were coated with $50 \mathrm{ng} /$ well of the $\mathrm{N}$-terminal
A $\beta$-specific antibody 82E1 (IBL-Hamburg, Hamburg, Germany) in PBS and blocked with 1\% BSA in PBS with $0.15 \%$ Kathon (Rohm \& Haas, Philadelphia, PA). Brain tissues homogenized in RIPA-buffer were supplemented with formic acid (to a final concentration of $70 \%$ ), neutralized with $1 \mathrm{M}$ Tris ( $\mathrm{pH} 10)$ and diluted in ELISA incubation buffer (PBS with $0.1 \%$ BSA and $0.05 \%$ Tween-20). Samples or standard (recombinant Arctic A $\beta 1-40$ ), were treated similarly, and added to the plates in duplicates and incubated for $2 \mathrm{~h}$ at room temperature with shaking. Biotinylated mAb27 $(1 \mu \mathrm{g} / \mathrm{ml})$, with a conformation-dependent epitope in the mid-domain of Arctic $A \beta$ [28], was used to measure total $A \beta$. The biotinylated detection antibody as well as streptavidinhorseradish peroxidase (SA-HRP; diluted 1:2000; Mabtech, Nacka, Sweden) was allowed to incubate for $1 \mathrm{~h}$ in successive steps. K-blue aqueous (ANL-Produkter, Älvsjö, Sweden) was used as HRP-substrate, the reaction was stopped with $1 \mathrm{M} \mathrm{H}_{2} \mathrm{SO}_{4}$ and the optical density was measured at $450 \mathrm{~nm}$ with a SpectraMax 190 (Molecular Devices, Sunnyvale, CA). Wells were washed three times between each step in ELISA washing buffer (PBS with $0.1 \%$ Tween-20 and $0.15 \%$ Kathon).

\section{Western blot}

Protein concentrations were estimated using Bicinchoninic acid assay (BCA, Pierce). Protein lysates $(20 \mu \mathrm{g} /$ lane from primary astro-microglial cultures and $40 \mu \mathrm{g} /$ lane from transgenic mice tissues) were mixed with Laemmli sample buffer and boiled for $5 \mathrm{~min}$. Proteins were separated on $12 \%$ SDS-polyacrylamide gels and thereafter blotted onto polyvinylidene diflouride (PVDF) membranes (Amersham Pharmacia). For analysis of oligomerand fibril-enriched $A \beta$ preparations, samples were not preheated and they were run on a $12 \%$ SDS-polyacrylamide gel without stacking gel. The membranes were incubated in PBS containing 5\% milk, 0.1\% Tween-20 (Bio-Rad) and 0.1\% BSA (Sigma) for $2 \mathrm{~h}$ at room temperature to block unspecific binding, and thereafter incubated in the above-mentioned PBS solution with primary antibody overnight at $4^{\circ} \mathrm{C}$. Antibody concentrations were as follows: $\mathrm{C} / \mathrm{EBP} \alpha((14 \mathrm{AA}) \mathrm{X})$ and $\mathrm{C} / \mathrm{EBP} \delta$ ((C-22)X, Santa Cruz Biotechnologies) 1:4000 for primary astro-microglial cultures and 1:1000 for transgenic samples, $\beta$-actin (A-2066, Sigma) 1:5000 and 6E10 (ab49682, Abcam) raised against $A \beta(1-17)$ 1:2000. Next, membranes were washed in PBS containing $2.5 \%$ milk and $0.1 \%$ Tween-20 for $4 \times 15 \mathrm{~min}$ and thereafter incubated with secondary antibody HRP coupled anti-rabbit IgG or anti-mouse IgG (GE Healthcare) 1:5000, diluted in the same solution, for $1 \mathrm{~h}$ at room temperature. Finally, membranes were washed $4 \times 15 \mathrm{~min}$ in PBS containing $0.1 \%$ Tween-20. Blots were incubated in ECL Plus reagents (GE Healthcare) for $5 \mathrm{~min}$ and exposed to 
Hyper film (GE Healthcare). Membranes exposed to anti-C/EBP $\beta$ ((C19)X, Santa Cruz Biotechnologies) were first washed $5 \mathrm{~min}$ in TBS and rinsed $10 \mathrm{~s}$ in methanol [29]. Thereafter the membranes were allowed to dry before overnight incubation at $4{ }^{\circ} \mathrm{C}$ with primary antibody, 1:500, diluted in TBS containing $5 \%$ milk and $0.05 \%$ Tween-20. Membranes were then washed $2 \times 15$ $\mathrm{s}$ in TBS containing $0.05 \%$ Tween-20 and incubated for $1 \mathrm{~h}$ at RT with secondary antibody (HRP coupled antirabbit IgG) 1:5000, diluted in TBS containing 5\% milk and $0.05 \%$ Tween-20. Finally, membranes were washed $2 \times 30 \mathrm{~min}$ in TBS containing $0.05 \%$ Tween-20, incubated in ECL Plus reagents for $5 \mathrm{~min}$ and exposed to Hyper film.

\section{Electrophoretic mobility shift assay (EMSA)}

Protein concentrations were established using BCA assay. EMSA was performed as previously described $[21,30]$ with minor modifications. Briefly, C/EBP sense oligonucleotide 5'-TGCAGATTGCGCAATCTGCA-3 (MWG) was labeled with $\gamma-{ }^{32} \mathrm{P}$ dATP (Perkin Elmer) using T4 polynucleotide kinase (Fermentas). Nuclear extracts $(5 \mu \mathrm{g})$ from primary astro-microglial cultures were incubated with anti-C/EBP $\delta$ ((C-22) X, Santa Cruz Biotechnologies) for $30 \mathrm{~min}$ at room temperature prior to binding reaction with ${ }^{32} \mathrm{P}$-labeled probe. Samples were separated on a $5 \%$ polyacrylamide gel at $150 \mathrm{~V}$ for $1 \mathrm{~h}$. Gels were exposed to a phosphorimager screen overnight.

\section{Streptavidin-agarose pull-down assay}

$\mathrm{C} / \mathrm{EBP} \delta$ binding to the $\kappa \mathrm{B}$ DNA element was analyzed by streptavidin-agarose pull-down [31,32]. Single stranded biotinylated $\kappa \mathrm{B}$ sense oligonucleotide 5'AGTTGAGGGGACTTTCCCAGGC-3' and antisense oligonucleotide 5'-GCCTGGGAAAGTCCCCTCAACT3' (MWG), were hybridized by incubation at $100^{\circ} \mathrm{C}$ for 1 $\mathrm{h}$ and then allowed to cool down slowly (for approx. 30 $\mathrm{min})$ to room temperature. Nuclear extracts $(150 \mu \mathrm{g})$ from primary astro-microglial cultures were mixed with streptavidin-agarose bead suspension (according to the manufacturer's recommendation; S1638, Sigma) and 4 $\mu \mathrm{g}$ of double stranded biotinylated oligonucleotides in $500 \mu \mathrm{l}$ of buffer B2 (PBS, $1 \mathrm{mM}$ EDTA, $1 \mathrm{mM}$ DTT, protease inhibitor cocktail Complete (Roche Diagnostics)). The mixture was then placed on a shaking platform for $2 \mathrm{~h}$ at room temperature. Thereafter the samples were centrifuged at $550 \mathrm{~g}$ for $1 \mathrm{~min}$ and the pellet washed 3 times in buffer B2. Finally the pellet was dissolved in $35 \mu \mathrm{l} 2 \mathrm{x}$ Laemmli sample buffer, incubated at $100^{\circ} \mathrm{C}$ for $5 \mathrm{~min}$ and centrifuged at $7000 \mathrm{~g}$ for $30 \mathrm{~s}$ and the supernatant was collected. Samples were loaded on a $12 \%$ SDS-polyacrylamide gel and analyzed by western blot. As a control for unspecific binding to the agarose beads, identical $\kappa \mathrm{B}$ oligonucleotides lacking biotin were used.

\section{Statistical analysis}

Data was analyzed using student's t-test or one-way ANOVA followed by Tukey's post hoc test.

\section{Results}

Fibril-enriched $A \beta$ preparations down-regulate levels of $C /$ EBP $\delta$ in activated primary astro-microglial cells

The effect of $\mathrm{A} \beta$ on expression levels of C/EBP $\alpha$ and $\delta$ in primary astro-microglial cells was analyzed by western blot. Two different preparations of $A \beta 1-42$ were used: one containing high levels of oligomers and one containing high levels of fibrils. The different $A \beta$ preparations were analyzed using western blot and Thioflavin $T$ assay (Figure $1 A, B$ ). Cells were treated with $A \beta$ enriched in oligomers or fibrils in the presence or absence of IL-1 $\beta$ (10 ng/ml) for $3 \mathrm{~h}$ prior to harvesting and preparing nuclear extracts. IL-1 $\beta$, which is known to be induced in AD brains, was used to activate the cells. For comparison, cells were also treated with LPS $(1 \mu \mathrm{g} / \mathrm{ml})$. Two different isoforms of C/EBP $\alpha$; 330 and p42, which were both significantly down-regulated by LPS treatment, were detected (Figure 1C,D and 2A,B). This is consistent with earlier findings in primary glial cultures showing that $\mathrm{C} / \mathrm{EBP} \alpha$ is mainly regulated through toll-like receptors [33]. Neither A $\beta$ nor IL-1 $\beta$ alone had any effect on the levels of the two isoforms of $\mathrm{C} / \mathrm{EBP} \alpha$. However, it should be noted that the levels of p30 and p42 appeared to be reduced when cell cultures were stimulated with fibril-enriched $A \beta$ preparations together with IL-1 $\beta$ although this effect was not statistically significant.

Both IL-1 $\beta$ and LPS induced up-regulation of C/ $\mathrm{EBP} \delta$ (Figure $1 \mathrm{C}, \mathrm{E}$ and $2 \mathrm{~A}, \mathrm{C}$ ). $\mathrm{A} \beta$ enriched in oligomers (Figure $1 \mathrm{C}, \mathrm{E}$ ) or fibrils (Figure $2 \mathrm{~A}, \mathrm{C}$ ) did not have any significant effect on basal C/EBP $\delta$ levels. However, treatment with $A \beta$ containing high levels of fibrils did significantly decrease IL- $1 \beta$-induced $\mathrm{C} / \mathrm{EBP} \delta$ levels by $\sim 75 \%$ (Figure $2 \mathrm{~A}, \mathrm{C}$ ). Neither $\mathrm{A} \beta$ preparations devoid of fibrils nor the reversed peptide $A \beta 42-1$ (prepared as the $A \beta 1-42$ ), used as a control, had any effect on IL-1 $\beta$-stimulated up-regulation of $\mathrm{C} / \mathrm{EBP} \delta$ (Figure $1 \mathrm{C}, \mathrm{E}$ and $2 \mathrm{~A}, \mathrm{C}$ ).

\section{C/EBP $\delta$ levels are decreased in brain areas of $\mathrm{tg}$-ArcSwe mice rich in amyloid plaques}

Based on these results, the effects of $\mathrm{A} \beta$ fibrils in vivo were investigated. Tg-ArcSwe mice (15.5-17-monthsold), with both the Artic (E693G) and Swedish (KM670/ $671 \mathrm{NL}$ ) APP double mutations, were chosen since aged animals exhibit an abundance of $A \beta$ fibrils [26]. A significant down-regulation of $\mathrm{C} / \mathrm{EBP} \alpha$ was found in both 


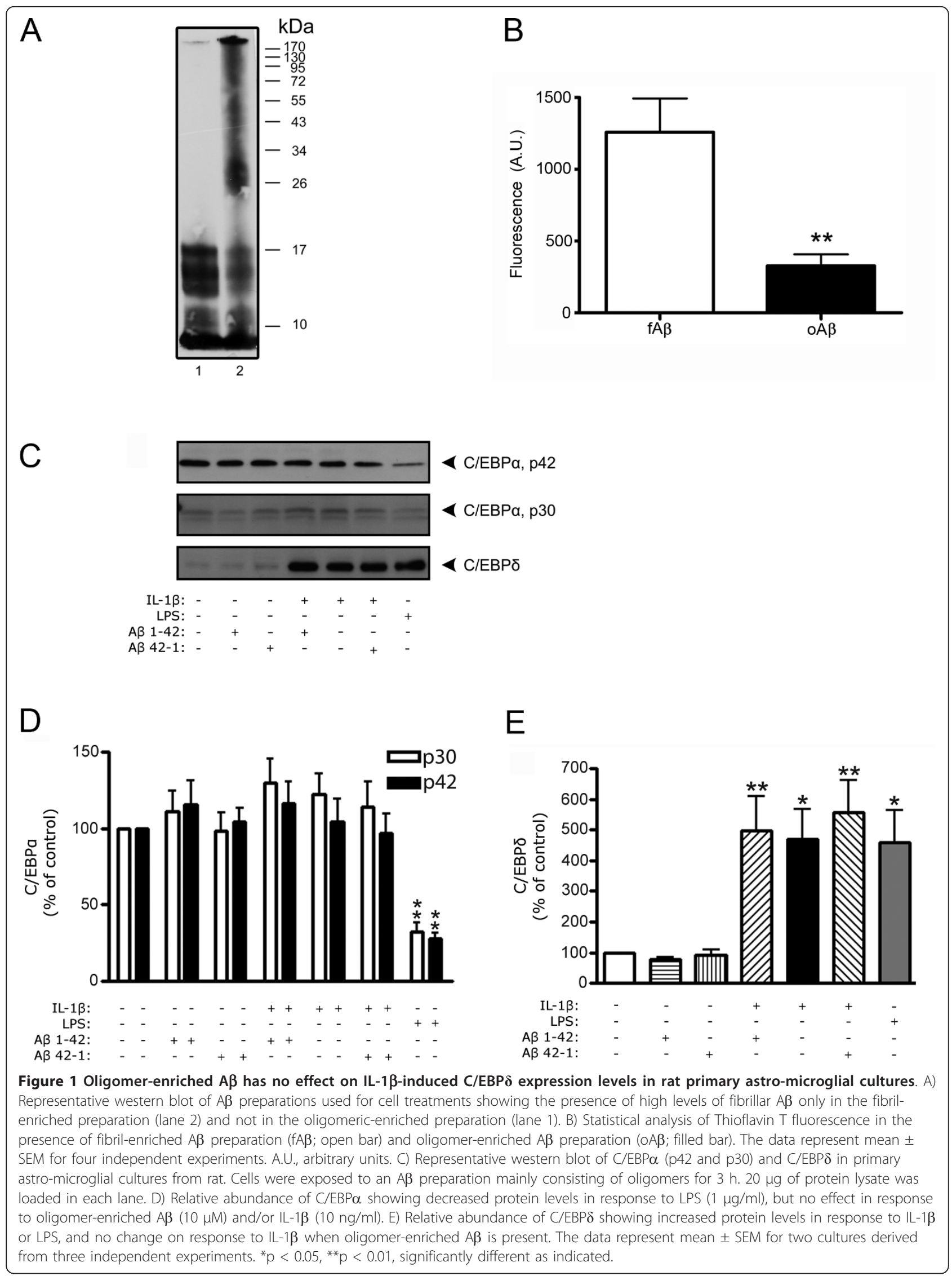




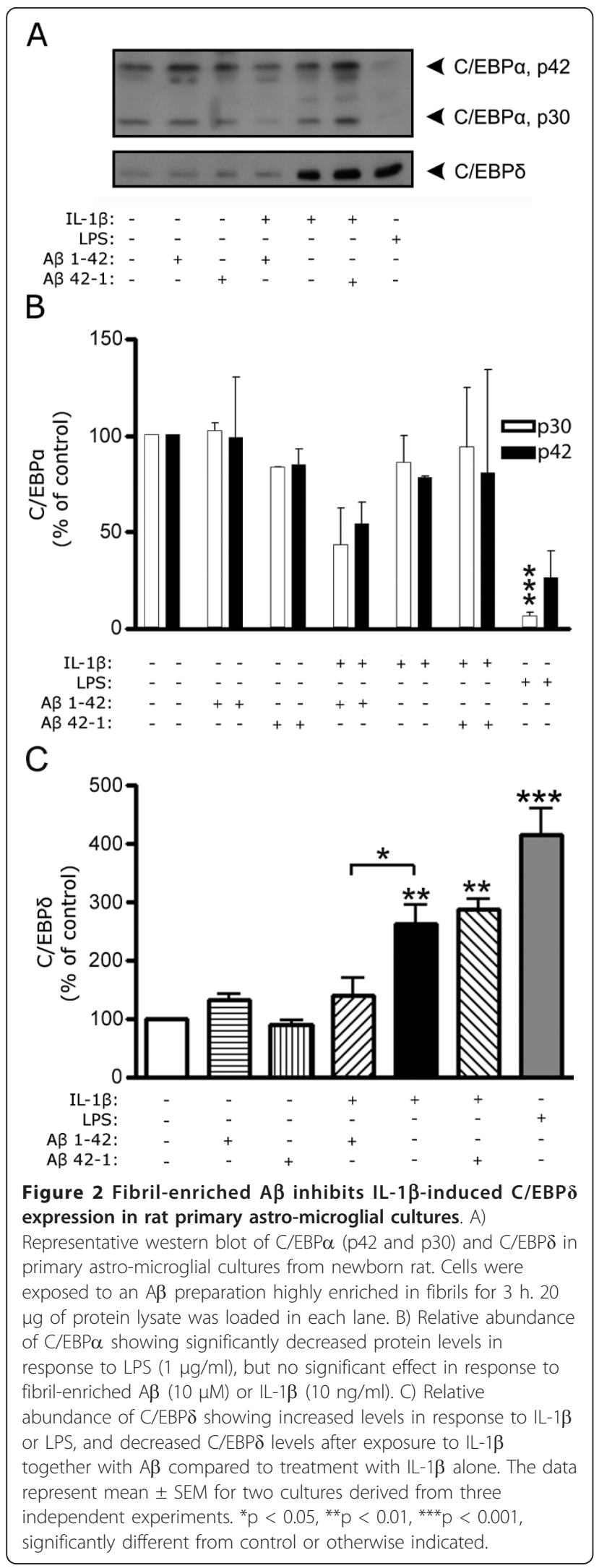

forebrain and hindbrain of aged tg-ArcSwe mice. C/EBP $\alpha$ p30 levels were $31-33 \%$ lower compared with age-matched non-transgenic littermates (Figure 3A,B). Unfortunately the effect on $\mathrm{p} 42$ could not be determined due to co-migration of strong nonspecific bands on the western blots. In contrast to a previous report of findings in human AD patient tissue [20], the levels of C/EBP $\delta$ were decreased $\sim 62 \%$ in forebrain of aged tgArcSwe mice compared with age-matched non-transgenic mice (Figure 4A). Total $\mathrm{A} \beta$ levels in forebrain from these aged tg-ArcSwe mice were $227 \pm 48 \mathrm{ng} \mathrm{A} \beta$ / mg tissue (mean $\pm \mathrm{SEM}, \mathrm{N}=6$ ) and were below the detection limit (i.e., $<20 \mathrm{pg} A \beta / \mathrm{mg}$ tissue) in non-transgenic mice. Our findings are consistent with the results from IL- $1 \beta$-activated astro-microglial cultures treated with fibrilar $A \beta$ (Figure $2 \mathrm{~A}, \mathrm{C}$ ). Analysis of the relatively $A \beta$ plaque-free hindbrain showed a down-regulation of $\mathrm{C} / \mathrm{EBP} \alpha \mathrm{p} 30$ levels similar to that found in forebrain (Figure $3 \mathrm{~B}$ ) indicating that this is not a local $\mathrm{A} \beta$ plaquedependent phenomenon. In contrast, no difference in $\mathrm{C} /$ EBP $\delta$ levels was observed in hindbrain when transgenic mice and non-transgenic age-matched littermates were compared (Figure 4B). To ensure that the changes in levels of C/EBPs were due to age-dependent accumulation of $A \beta$ and formation of $A \beta$ fibrils, and not some unrelated effect of the transgene, brain tissue from young tg-ArcSwe mice with low $A \beta$ load were analyzed and compared with age-matched non-transgenic mice. These experiments showed that there are no significant differences between tg-ArcSwe mice and non-transgenic mice with respect to C/EBP $\alpha$ p30 (Figure 3C,D) and C/ EBP $\delta$ levels (Figure 4C,D). However, direct comparison of non-transgenic and tg-ArcSwe mice of different ages indicated that $\mathrm{C} / \mathrm{EBP} \delta$ levels are down-regulated both in response to age and $A \beta$ plaque burden (Figure $5 \mathrm{~A}, \mathrm{~B}$ ). The C/EBP $\delta$ levels in forebrain were significantly decreased in aged non-transgenic mice by $\sim 51 \%$ and further decreased in aged tg-ArcSwe mice by 92\% compared to young animals. In contrast, the LAP isoform $(\sim 35 \mathrm{kDa})$ of $\mathrm{C} / \mathrm{EBP} \beta$ was significantly up-regulated ( $27 \%$ higher) in the forebrain of aged tg-ArcSwe mice as compared to age-matched non-transgenic control (Figure 6A,B). C/EBP $\beta$ LAP levels were below or close to detection limit in the hindbrain of aged mice and in both forebrain and hindbrain of young animals and could therefore not be quantified.

\section{IL-1 $\beta$-increased binding activity of C/EBP $\delta$ is blocked by fibril-enriched $A \beta$ preparations}

To further investigate the effects of fibrillar forms of $A \beta$, EMSA was performed to analyze C/EBP $\delta$ binding activity. Primary astro-microglial cells were treated for 


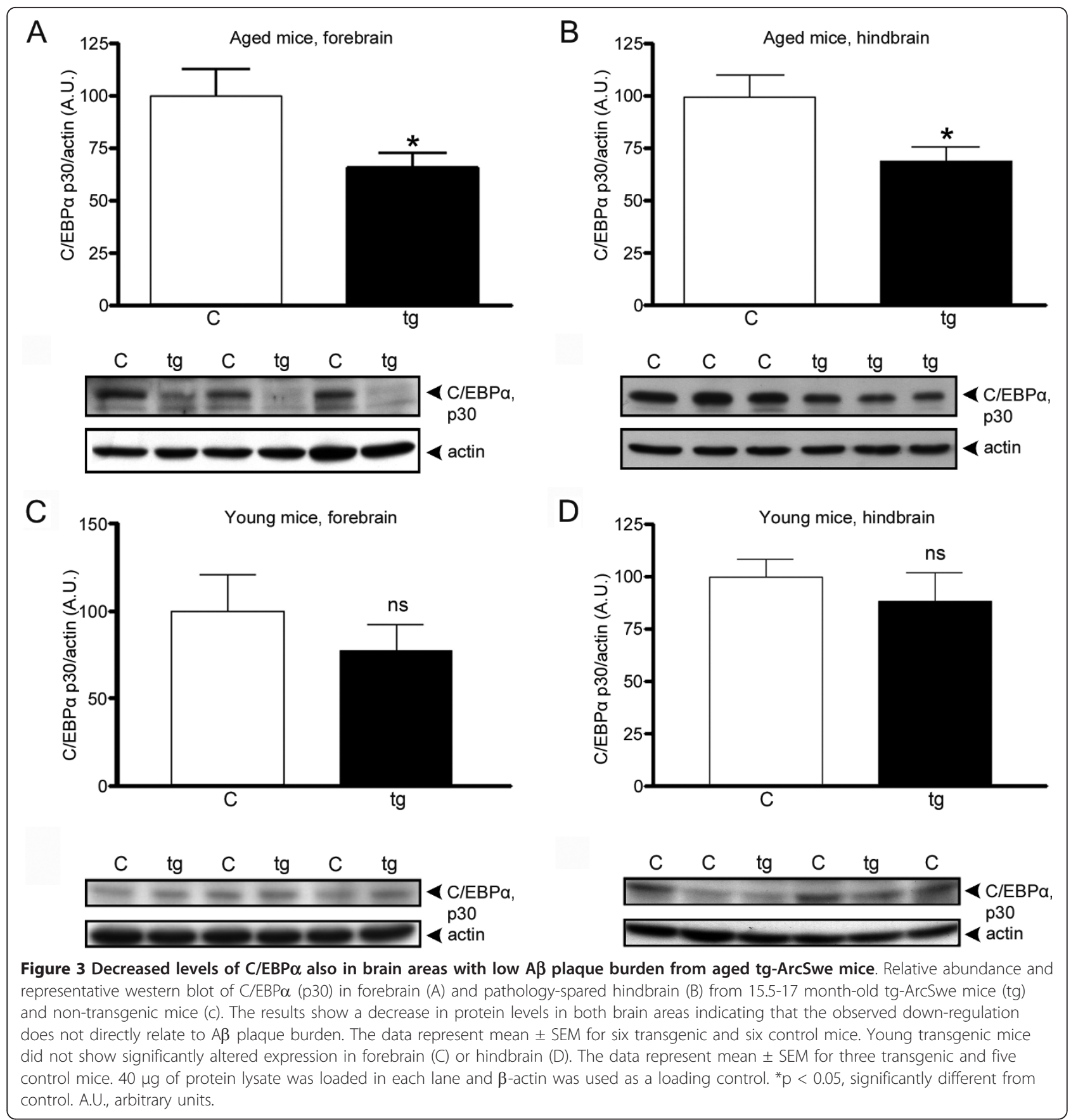

$3 \mathrm{~h}$ with $\mathrm{A} \beta$ fibrils in the presence or absence of IL- $1 \beta$ prior to harvesting. The results show that C/EBP $\delta$ binding to double-stranded oligonucleotides containing a C/EBP binding site is down-regulated by $\sim 89 \%$ in cultures concomitantly treated with IL- $1 \beta$ and fibrilenriched $A \beta$ preparations compared to cells treated with IL-1 $\beta$ alone (Figure 7A,B). The down-regulation in DNA binding activity reflects the down-regulation in protein level.
C/EBP $\delta$ binding to a $\kappa \mathrm{B}$ site induced by IL-1 $\beta$ is inhibited by $A \beta$

In order to test the hypothesis that $\mathrm{C} / \mathrm{EBP} \delta$ can shift its preferable DNA binding site and binding partners, and to analyze the effects of $\mathrm{A} \beta, \mathrm{C} / \mathrm{EBP} \delta$ binding to a $\kappa \mathrm{B}$ response element was investigated. Nuclear extracts from primary astro-microglial cultures treated for $3 \mathrm{~h}$ with IL-1 $\beta$ together with $A \beta$ were analyzed in streptavidin-agarose pull-down experiments. Cells treated with 


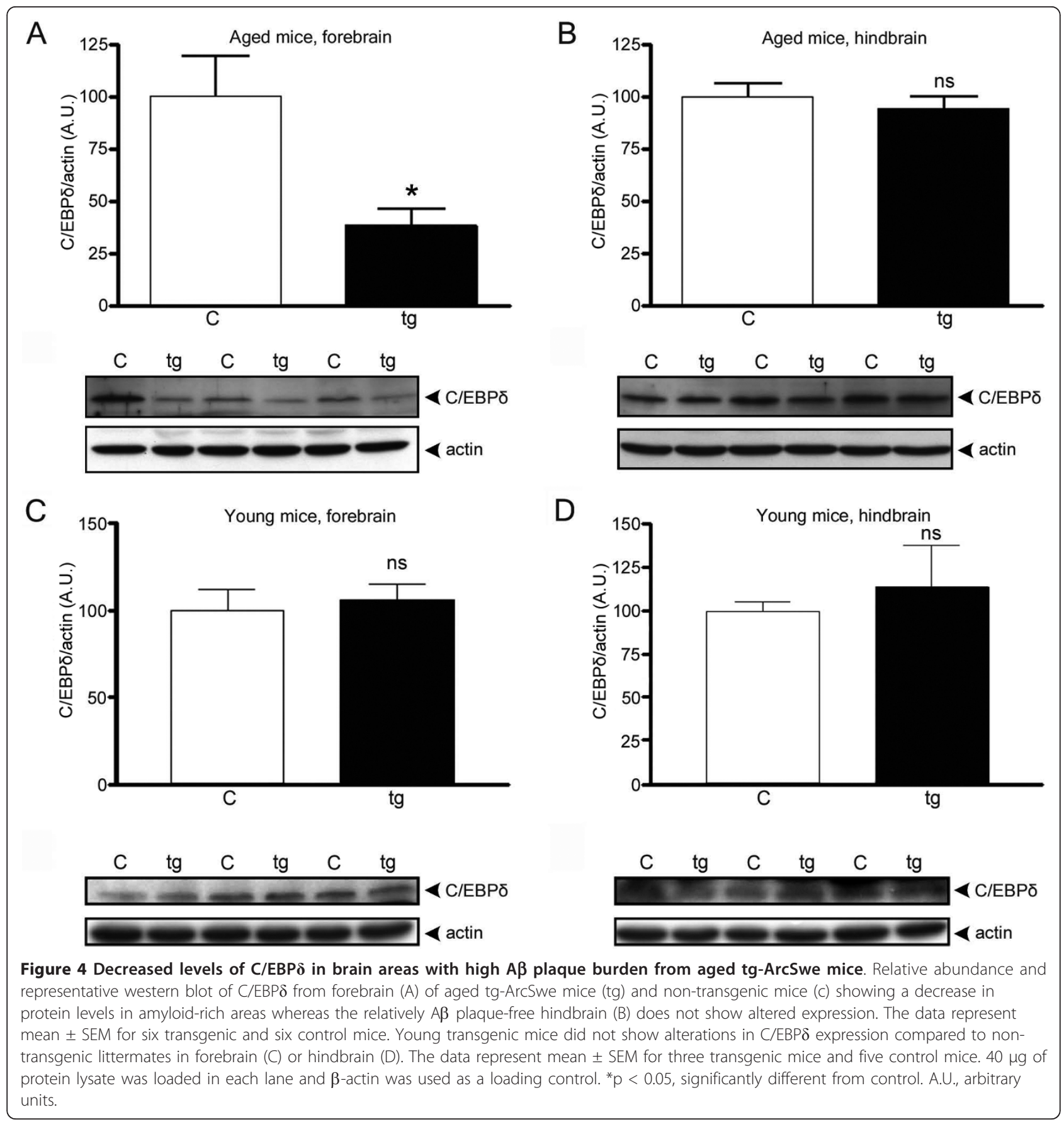

IL- $1 \beta$ showed increased binding to the $\kappa \mathrm{B}$ element compared to untreated control cells. In the presence of fibril-enriched $\mathrm{A} \beta$, IL- $1 \beta$-induced binding of $\mathrm{C} / \mathrm{EBP} \delta$ to the $\kappa \mathrm{B}$ site was completely blocked (Figure $8 \mathrm{~A}, \mathrm{~B}$ ). We also analyzed the effect of oligomer-enriched preparations of A $\beta$. Surprisingly, the oligomeric conformation of $\mathrm{A} \beta$ decreased $\mathrm{C} / \mathrm{EBP} \delta$ binding to the $\kappa \mathrm{B}$ site to the same extent as the fibrillar form in IL-1 $\beta$ activated cells (Figure 8A,B).

\section{Discussion}

In this study we observed that IL- $1 \beta$-induced expression of $\mathrm{C} / \mathrm{EBP} \delta$ was inhibited in rat primary astro-microglial cultures after exposure to $A \beta$. However, this effect is dependent on the presence of fibrillar forms of $A \beta$ and no effect on protein levels was observed after exposure to an oligomer-enriched $A \beta$ preparation. In general, $C /$ EBP $\delta$ is up-regulated in response to inflammatory stimuli. Our results instead indicate an $A \beta$-dependent 


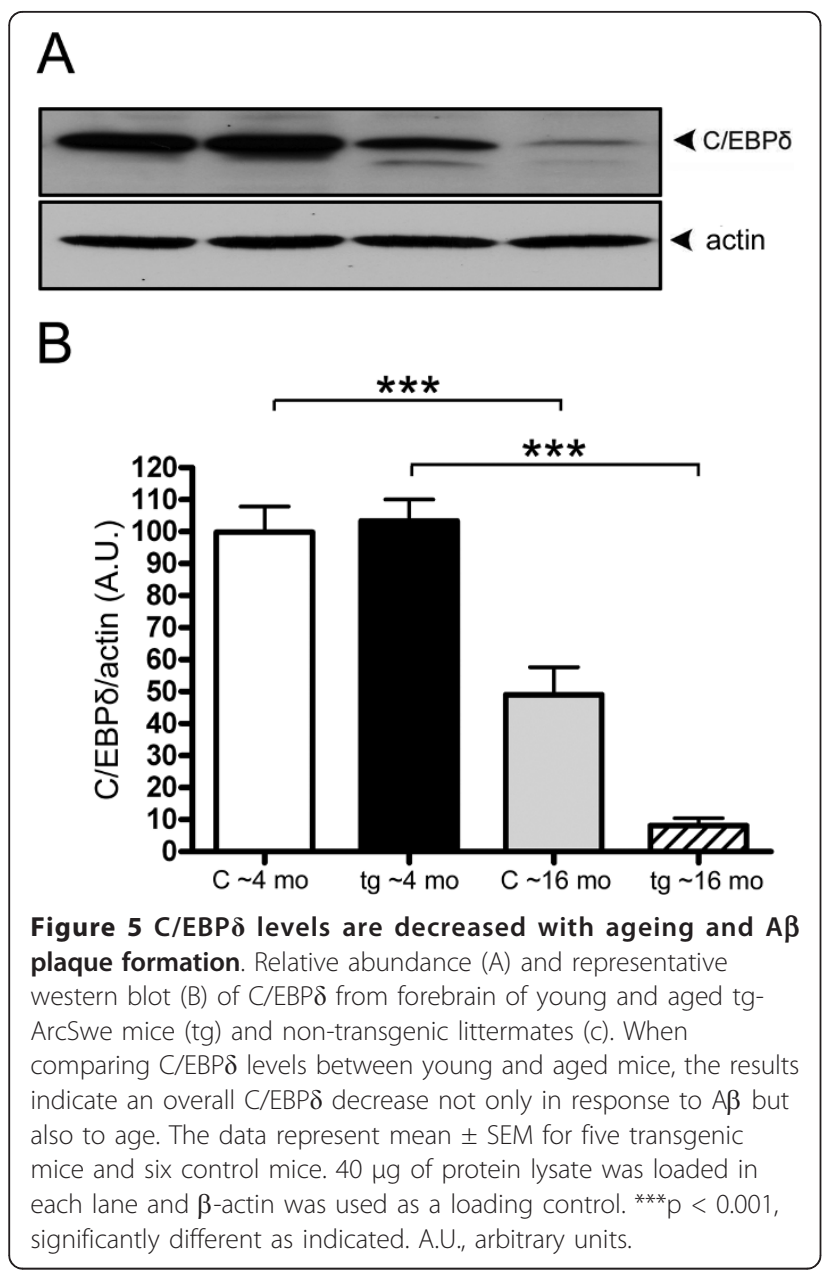

decrease in $\mathrm{C} / \mathrm{EBP} \delta$ levels. This decrease of $\mathrm{C} / \mathrm{EBP} \delta$ was further confirmed using an AD transgenic mouse model, tg-ArcSwe mice, characterized by high levels of fibrillar A $\beta$ deposits [25]. When analyzing brain areas of aged mice carrying a high $\mathrm{A} \beta$ load, $\mathrm{C} / \mathrm{EBP} \delta$ was significantly down-regulated compared to the same brain areas from aged non-transgenic littermates. This effect on $\mathrm{C} / \mathrm{EBP} \delta$ levels is not the expected result since upregulation of inflammatory markers has been detected in other AD transgenic mice models (cf., [34]). An A $\beta$ induced inflammatory response in $\mathrm{tg}$-ArcSwe mice is, however, supported by down-regulated $\mathrm{C} / \mathrm{EBP} \alpha$ levels and up-regulated $C / E B P \beta$ levels in forebrain from aged $\operatorname{tg}$-ArcSwe mice.

Differential effects of oligomeric and fibrillar forms of $\mathrm{A} \beta$ on glial cells have been reported earlier: Rat astromicroglial cultures show significantly higher levels of inflammatory markers, such as tumor necrosis factor (TNF)- $\alpha$, when exposed to oligomeric compared to fibrillar $A \beta$ [35]. In microglial cells TNF- $\alpha$ induction is typical for a classic cytotoxic phenotype, whereas an alternative activation state is not correlated with

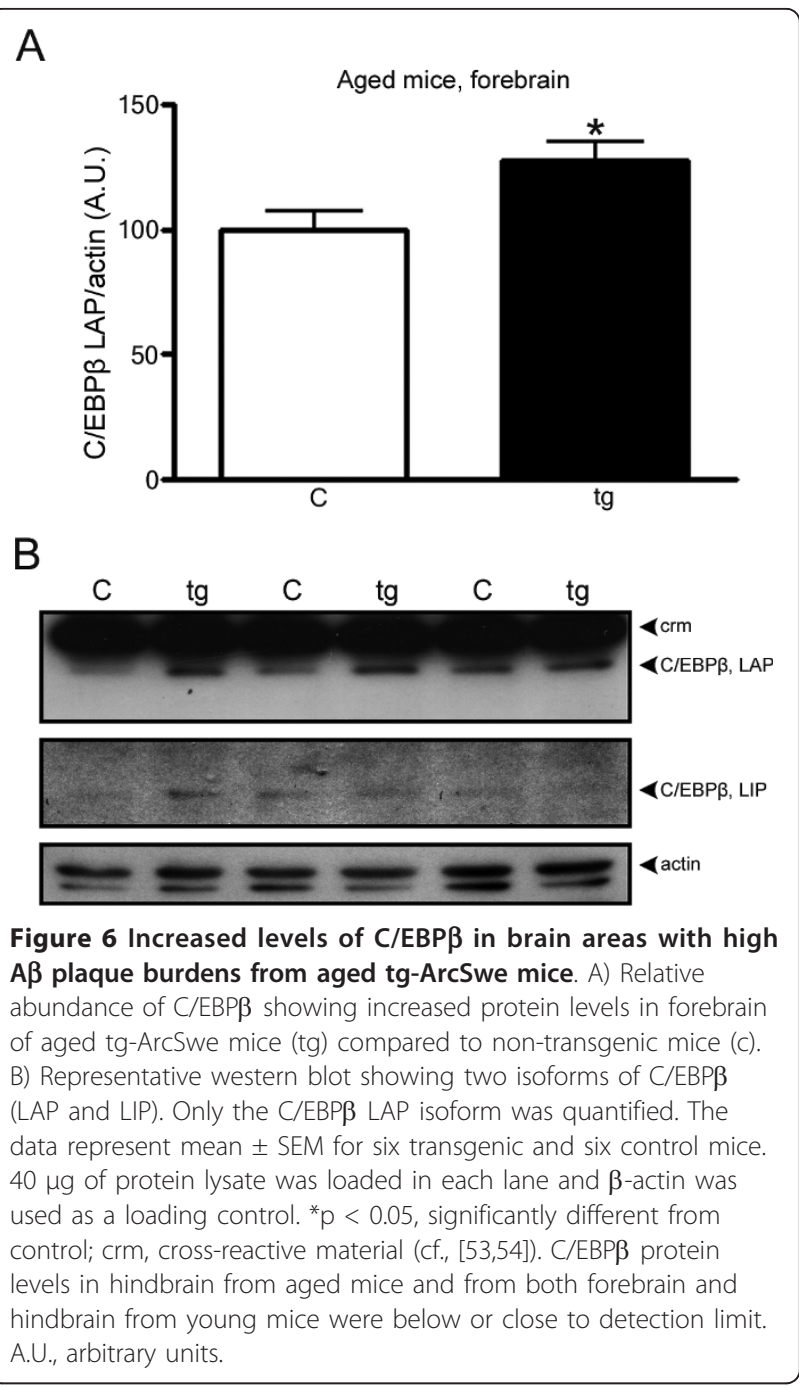

expression of inflammatory cytokines and is instead characterized by increased $A \beta$ phagocytic capabilities. A recent study in a PS1 $x A P P$ transgenic AD model showed that hippocampal microglial cells switch from the alternative activation state to the classical cytotoxic phenotype during aging [36]. Interestingly, only microglia not located in the vicinity of $A \beta$ plaques express this classical cytotoxic phenotype in 18-month-old transgenic mice. Microglial cells surrounding plaques are instead TNF- $\alpha$ negative. The same authors also showed that both oligomeric A $\beta$ and soluble extract from 18-monthold transgenic mouse hippocampus produces potent TNF- $\alpha$ induction in astro-microglial cultures from nontransgenic mice [36]. One possibility is that increased expression of $\mathrm{C} / \mathrm{EBP} \delta$ is a marker for classical cytotoxic glial cells and that the fibrillar form of $A \beta$ actually blocks induction of this phenotype. This could also explain the decreased levels of $\mathrm{C} / \mathrm{EBP} \delta$ that we observed in brain areas with high $A \beta$ load in aged tg-ArcSwe 


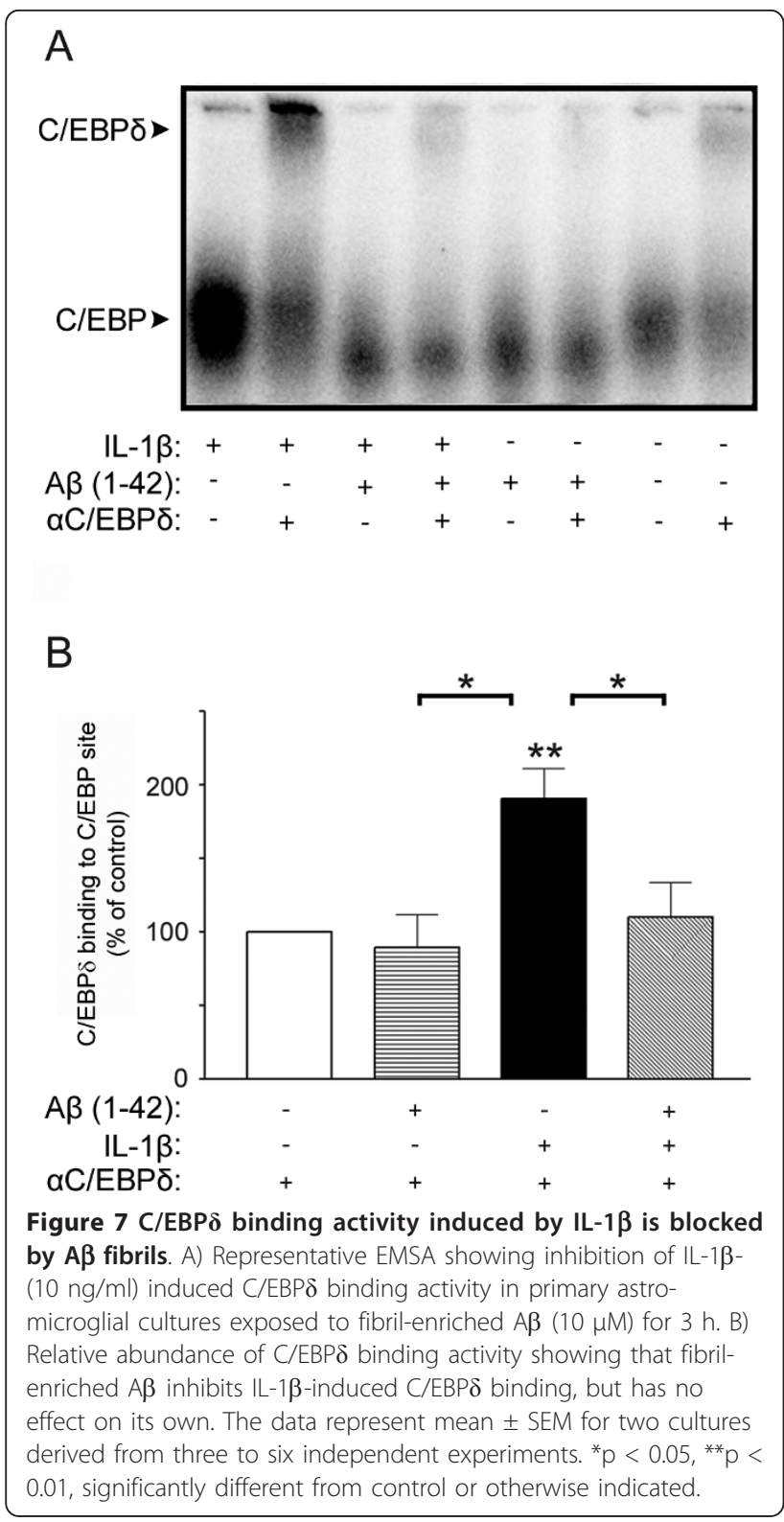

mice, since the Arctic mutation not only increases the rate of $\mathrm{A} \beta$ protofibril formation but also fibril formation and senile plaque deposition [26,37].

As indicated above, increased levels of C/EBP $\beta$ and $\delta$ are expected when an inflammatory response is induced. It is believed that during inflammation the rapidly and transiently activated NF- $\kappa \mathrm{B}$ pathway is crucial for a primary wave of gene induction and that a second and more long-term wave of gene transcription is mediated by other transcription factors including the $\mathrm{C} / \mathrm{EBP}$ family (cf., $[12,38,39]$ ). Members of the C/EBP family can form heterodimers with NF- $\kappa$ B subunits [9,11]. Previous studies have indicated a reciprocal cross-coupling between NF- $\kappa$ B and C/EBPs: NF- $\kappa$ B and C/EBPs seem

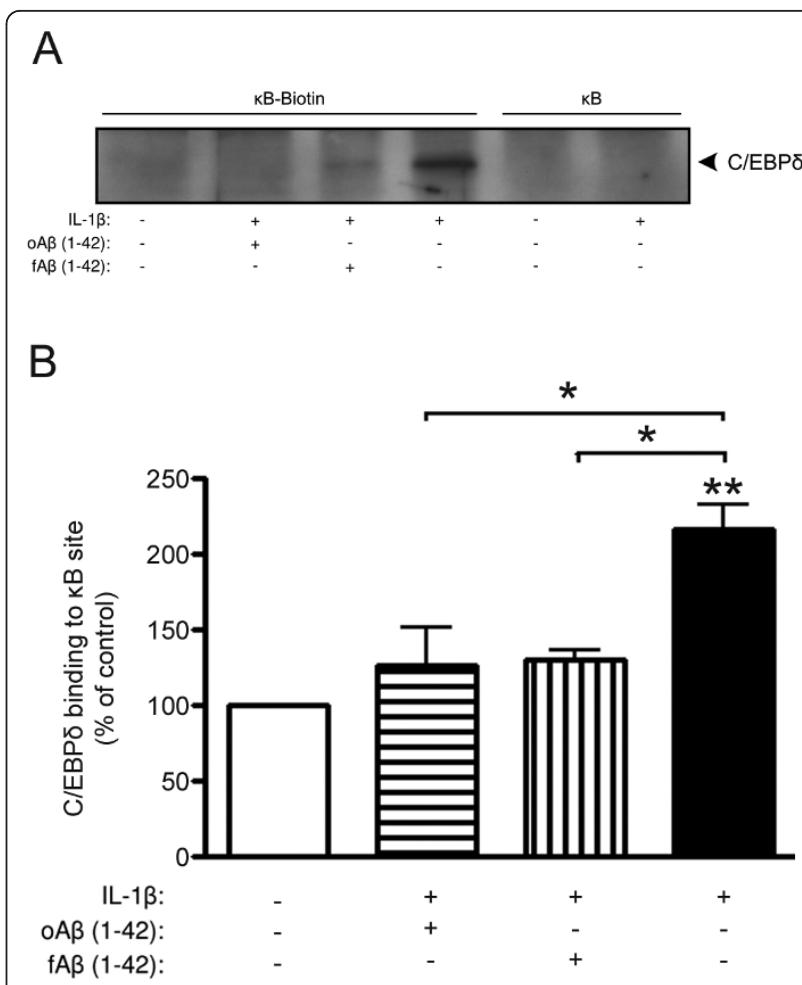

Figure 8 IL-1 $\beta$-induced C/EBP $\delta$ binding to a $\kappa$ B site is inhibited by $A \boldsymbol{\beta}$. A) Representative western blot of C/EBP $\delta$ after streptavidinagarose pull-down using biotinylated $\kappa \mathrm{B}$ oligonucleotides. Primary astro-microglial cells were exposed to oligomer- or fibril-enriched preparations of $A \beta(10 \mu \mathrm{M}, \mathrm{OA} \beta$ or $\mathrm{f} A \beta)$ in combination with $\mathrm{IL}-1 \beta$ $(10 \mathrm{ng} / \mathrm{ml})$ for $3 \mathrm{~h}$. $\kappa \mathrm{B}$ oligonucleotides without biotin were used as a control for unspecific binding. B) Relative levels of C/EBP $\delta$ binding to the $\kappa \mathrm{B}$ site showing that IL-1 $\beta$ induces a significant increase that is inhibited after $A \beta$ exposure. The data represent mean \pm SEM for three independent experiments. ${ }^{*} p<0.05,{ }^{* *} p<0.01$, significantly different from control or otherwise indicated.

to synergistically activate promoters with C/EBP sites, and inhibit promoters with $\kappa \mathrm{B}$ motifs $[10,38,40]$. In this study we show that, in astro-microglial cells, IL-1 $\beta$ induces binding of $\mathrm{C} / \mathrm{EBP} \delta$-containing complexes to a $\kappa \mathrm{B}$ site. It could be speculated that this is a part of a negative feed-back mechanism regulating the effect of NF $-\kappa \mathrm{B}$ activation. If this is true, the inhibition of $\mathrm{C} /$ $\mathrm{EBP} \delta$ binding to the $\kappa \mathrm{B}$ motif that we observe after exposure to $A \beta$ could result in prolonged effects of NF$\kappa \mathrm{B}$ acting at this site.

When the astro-microglial cells were exposed to fibrilenriched $A \beta$ preparations the IL- $1 \beta$-induced binding of $\mathrm{C} / \mathrm{EBP} \delta$ to both the $\mathrm{C} / \mathrm{EBP}$ and the $\kappa \mathrm{B}$ motifs were more or less abolished. This could be expected since the IL- $1 \beta$-induced increase of $\mathrm{C} / \mathrm{EBP} \delta$ protein levels was strongly reduced by $A \beta$ fibrils. However, the effect of oligomer-enriched $A \beta$ preparations on $\mathrm{C} / \mathrm{EBP} \delta$ binding activity was not expected. Although no effect could be observed on protein levels, IL- $1 \beta$-induced binding of $\mathrm{C} /$ 
$\mathrm{EBP} \delta$ to the $\kappa \mathrm{B}$ site was decreased to the same degree as after treatment with $A \beta$ fibrils. In addition, we showed in a previous study that oligomer-enriched $A \beta$ preparations also decrease the binding of $\mathrm{C} / \mathrm{EBP} \delta$ to the $\mathrm{C} / \mathrm{EBP}$ site [21]. Taken together these results indicate that oligomer-enriched $A \beta$ affects the functional properties of $\mathrm{C} / \mathrm{EBP} \delta$ rather than expression levels.

The activity of C/EBPs has been shown to be dependent upon phosphorylation. Phosphorylation can occur in a negative regulatory domain of C/EBPs and is believed to relieve the inhibitory effect on their DNA binding and transactivation domains $[41,42]$. C/EBP $\beta$ has a conserved MAPK consensus phosphorylation motif [43]. Phosphorylation induced by the Ras pathway upon inflammatory stimuli will lead to a switch from a repressed to an active conformation [43-45]. In murine embryonic fibroblasts, LPS-induced expression of both $\mathrm{C} / \mathrm{EBP} \beta$ and $\delta$ is dependent on NF- $\kappa \mathrm{Bp} 65$ and $\mathrm{I} \kappa \mathrm{B}$ kinase (IKK) 2 [46]. In cells lacking the IKK-related kinase IKKi, LPS will still activate NF- $\kappa \mathrm{B}$ and induce $\mathrm{C} /$ $\mathrm{EBP} \beta$ and $\delta$ expression, but $\mathrm{C} / \mathrm{EBP} \delta$-specific DNA binding is absent [46].

IL-1 $\beta$, as well as other inflammatory stimuli, has been shown to activate the Ras pathway [47]. The Ras pathway in turn can result in both extracellular signal-regulated kinase (ERK) $1 / 2$ and IKKi activation [48]. A recent study showed that LPS-induced upregulation of $\mathrm{C} / \mathrm{EBP} \delta$ in a microglial cell line could be prevented by an ERK inhibitor [31]. Both LPS-induced C/EBP $\delta$ protein expression and DNA binding to a C/EBP motif have been reported to be blocked by a combination of MAP kinase inhibitors (ERK/JNK/p38 inhibitors) [49]. Interestingly, an age-dependent and significant reduction of the active form of ERK1 (phosphoERK1; pERK1) has been observed in cerebral cortex from the AD-transgenic mouse model tg2576/PS1 ${ }^{\mathrm{P} 264 \mathrm{~L}}$ [50]. In addition, in the tg2576 mice model, which shows a slower build-up of amyloid burden, a slight, but significant, increase of pERK2 is observed in CA1 of hippocampus at 13 months of age. This is followed by a significant reduction at 20 months of age [51]. Thus, it is possible that our results showing decreased levels of $\mathrm{C} / \mathrm{EBP} \delta$ both in astro-microglial cultures exposed to $A \beta$ fibrils and in aged $\mathrm{tg}$-ArcSwe mice could be explained by reduced MAP kinase activity.

Our results showing decreased levels of $\mathrm{C} / \mathrm{EBP} \delta$ both in astro-microglial cultures exposed to $A \beta$ fibrils and in aged tg-ArcSwe mice seems contradictory to a previous study from Rogers' laboratory showing up-regulated C/ EBP $\delta$ in AD brains [20]. However, as discussed above, data from transgenic mouse models indicate that the effect on $\mathrm{C} / \mathrm{EBP} \delta$ may correlate with a later phase when build-up of fibrillar $A \beta$ deposits reaches a certain level that will lead to reduced expression of $\mathrm{C} / \mathrm{EBP} \delta$. It may be assumed that the ratio $A \beta$ fibrils:oligomers may be lower in brain tissue from patients with the sporadic form of $\mathrm{AD}$ as compared to aged tg-ArcSwe transgenic mice. However, it cannot be ruled out that DNA binding and transcriptional activity is reduced also in $\mathrm{AD}$ brain since we propose that oligomer-enriched $A \beta$ disturbs the functional properties of $\mathrm{C} / \mathrm{EBP} \delta$ rather than expression levels.

The C/EBP family members exert pleiotropic effects in tissues in which they are expressed and are also expressed in a number of different cell types. $\mathrm{C} / \mathrm{EBP} \alpha$, $\beta$, and $\delta$ are all expressed in primary astro-microglial cultures. At least in human AD brains, C/EBP $\delta$ immunoreactivity seems to localize primarily to astrocytes [20]. However, in brain tissue from mice neuronal localization of C/EBPs has also been reported [20,52] and this may also explain the high levels of $\mathrm{C} / \mathrm{EBP} \delta$ in young mice. At this point we have not identified the cell types which are responsible for the effects on tissue levels of $\mathrm{C} / \mathrm{EBP} \alpha, \beta$, and $\delta$ in tg-ArcSwe mouse brain. It is also possible that the differential effects on the different isoforms (i.e., decreased levels of $\mathrm{C} / \mathrm{EBP} \alpha$ in both affected and non-affected brain areas, increased levels of $\mathrm{C} / \mathrm{EBP} \beta$ in affected areas and decreased levels of $\mathrm{C} /$ EBP $\delta$ only in affected areas) mirror the effects of $A \beta$ deposits on different cell types.

\section{Conclusions}

Our results indicate that different aggregation states of $\mathrm{A} \beta$ affect the transcription factor $\mathrm{C} / \mathrm{EBP} \delta$ differently during inflammatory conditions. $A \beta$ oligomers, on the one hand, seem to have an effect on C/EBP $\delta$ function, as shown by reduced DNA binding activity induced by $\mathrm{IL}-1 \beta$, rather than affecting $\mathrm{C} / \mathrm{EBP} \delta$ protein levels. $A \beta$ fibrils, on the other hand, reduce both protein expression levels and binding activity to $\mathrm{C} /$ $\mathrm{EBP}$ and $\kappa \mathrm{B}$ sites. In vivo studies using aged plaquedepositing tg-ArcSwe mice further confirm down-regulation of $C / E B P \delta$ caused by the presence of $A \beta$ fibrils. We propose that AD pathology causes an imbalance between $\mathrm{NF}-\kappa \mathrm{B}$ and $\mathrm{C} / \mathrm{EBP}$ transcription factors that may result in abnormal responses to inflammatory stimuli. However, the functional consequences of a disturbed $\mathrm{C} / \mathrm{EBP} \delta$ signaling in $\mathrm{AD}$ remain to be determined.

\section{Acknowledgements}

This work was supported by the Swedish Research Council (\#2007-2798 to Kl; \#2009-4389 to LNGN), Gun and Bertil Stohnes Foundation (to KI and to LNGN), Demensfonden (to KI), Stiftelsen för Gamla Tjänarinnor (to VR and to LNGN), K \& A Wallenbergs Foundation (to VR), Stiftelsen Olle Engkvist Byggmästare (to LT), Sven and Dagmar Saléns Stiftelse (to LT), Alzheimerfonden (to LNGN), and Åhlensstiftelsen (to LNGN). The Uppsala University Transgenic Facility (UUTF) is greatly acknowledged for helping in developing APP transgenic models. 


\section{Author details}

'Department of Neurochemistry, Stockholm University, SE-10691 Stockholm; Sweden. ${ }^{2}$ Department of Public Health and Caring Sciences, Uppsala University, SE-75185 Uppsala, Sweden.

\section{Authors' contributions}

The original design of this study was made by VR, MS, KI. VR coordinated the experiments. VR and LT performed the western blot analyses. EMSA was performed by LT. Streptavidine-agarose pull-down assay and Thioflavin T assays were performed by VR. LNGN maintained the colony of transgenic mice, prepared and dissected brain tissues and performed A $B$ ELISA. LNGN and LT participated in the design of the study. VR, LT and KI wrote the first draft of the manuscript. All authors discussed the results and commented on the manuscript. All of the authors have read and approved the final version of the manuscript.

\section{Competing interests}

The authors declare that they have no competing interests.

Received: 18 October 2010 Accepted: 14 April 2011

Published: 14 April 2011

\section{References}

1. Gong Y, Chang L, Viola KL, Lacor PN, Lambert MP, Finch CE, Krafft GA Klein WL: Alzheimer's disease-affected brain: presence of oligomeric $A$ beta ligands (ADDLs) suggests a molecular basis for reversible memory loss. Proc Natl Acad Sci USA 2003, 100:10417-10422.

2. Haass C, Selkoe DJ: Soluble protein oligomers in neurodegeneration: lessons from the Alzheimer's amyloid beta-peptide. Nat Rev Mol Cell Biol 2007, 8:101-112

3. Meyer-Luehmann M, Spires-Jones TL, Prada C, Garcia-Alloza M, de Calignon A, Rozkalne A, Koenigsknecht-Talboo J, Holtzman DM, Bacskai BJ, Hyman BT: Rapid appearance and local toxicity of amyloid-beta plaques in a mouse model of Alzheimer's disease. Nature 2008, 451:720-724.

4. Kuchibhotla KV, Goldman ST, Lattarulo CR, Wu HY, Hyman BT, Bacskai B. Abeta plaques lead to aberrant regulation of calcium homeostasis in vivo resulting in structural and functional disruption of neuronal networks. Neuron 2008, 59:214-225.

5. Akiyama H, Barger S, Barnum S, Bradt B, Bauer J, Cole GM, Cooper NR, Eikelenboom P, Emmerling M, Fiebich BL, et al: Inflammation and Alzheimer's disease. Neurobiol Aging 2000, 21:383-421.

6. Simard AR, Soulet D, Gowing G, Julien JP, Rivest S: Bone marrow-derived microglia play a critical role in restricting senile plaque formation in Alzheimer's disease. Neuron 2006, 49:489-502.

7. Koistinaho M, Lin S, Wu X, Esterman M, Koger D, Hanson J, Higgs R, Liu F, Malkani S, Bales KR, Paul SM: Apolipoprotein E promotes astrocyte colocalization and degradation of deposited amyloid-beta peptides. Nat Med 2004, 10:719-726.

8. Funato H, Yoshimura M, Yamazaki T, Saido TC, Ito Y, Yokofujita J, Okeda R, Ihara Y: Astrocytes containing amyloid beta-protein (Abeta)-positive granules are associated with Abeta40-positive diffuse plaques in the aged human brain. Am J Pathol 1998, 152:983-992.

9. LeClair KP, Blanar MA, Sharp PA: The p50 subunit of NF-kappa B associates with the NF-IL6 transcription factor. Proc Natl Acad Sci USA 1992, 89:8145-8149.

10. Stein B, Baldwin AS Jr: Distinct mechanisms for regulation of the interleukin-8 gene involve synergism and cooperativity between C/EBP and NF-kappa B. Mol Cell Biol 1993, 13:7191-7198.

11. Stein B, Cogswell PC, Baldwin AS Jr: Functional and physical associations between NF-kappa B and C/EBP family members: a Rel domain-bZIP interaction. Mol Cell Biol 1993, 13:3964-3974.

12. Poli V: The role of C/EBP isoforms in the control of inflammatory and native immunity functions. J Biol Chem 1998, 273:29279-29282.

13. Fey GH, Gauldie J: The acute phase response of the liver in inflammation. Prog Liver Dis 1990, 9:89-116.

14. Alam T, An MR, Papaconstantinou J: Differential expression of three C/EBP isoforms in multiple tissues during the acute phase response. $J$ Biol Chem 1992, 267:5021-5024.

15. Cardinaux JR, Allaman I, Magistretti PJ: Pro-inflammatory cytokines induce the transcription factors C/EBPbeta and C/EBPdelta in astrocytes. Glia 2000, 29:91-97.
16. Ramji DP, Foka P: CCAAT/enhancer-binding proteins: structure, function and regulation. Biochem J 2002, 365:561-575.

17. Blalock EM, Geddes JW, Chen KC, Porter NM, Markesbery WR, Landfield PW: Incipient Alzheimer's disease: microarray correlation analyses reveal major transcriptional and tumor suppressor responses. Proc Natl Acad Sci USA 2004, 101:2173-2178.

18. Colangelo V, Schurr J, Ball MJ, Pelaez RP, Bazan NG, Lukiw WJ: Gene expression profiling of 12633 genes in Alzheimer hippocampal CA1: transcription and neurotrophic factor down-regulation and upregulation of apoptotic and pro-inflammatory signaling. J Neurosci Res 2002, 70:462-473.

19. Lukiw WJ: Gene expression profiling in fetal, aged, and Alzheimer hippocampus: a continuum of stress-related signaling. Neurochem Res 2004, 29:1287-1297.

20. Li R, Strohmeyer R, Liang Z, Lue LF, Rogers J: CCAAT/enhancer binding protein delta (C/EBPdelta) expression and elevation in Alzheimer's disease. Neurobiol Aging 2004, 25:991-999.

21. Samuelsson M, Ramberg V, Iverfeldt K: Alzheimer amyloid-beta peptides block the activation of C/EBPbeta and C/EBPdelta in glial cells. Biochem Biophys Res Commun 2008, 370:619-622.

22. Eriksson G, Peterson A, Iverfeldt K, Walum E: Sodium-dependent glutamate uptake as an activator of oxidative metabolism in primary astrocyte cultures from newborn rat. Glia 1995, 15:152-156.

23. Dahlgren KN, Manelli AM, Stine WB Jr, Baker LK, Krafft GA, LaDu MJ: Oligomeric and fibrillar species of amyloid-beta peptides differentially affect neuronal viability. J Biol Chem 2002, 277:32046-32053.

24. Stine WB Jr, Dahlgren KN, Krafft GA, LaDu MJ: In vitro characterization of conditions for amyloid-beta peptide oligomerization and fibrillogenesis. J Biol Chem 2003, 278:11612-11622.

25. Lord A, Kalimo H, Eckman C, Zhang XQ, Lannfelt L, Nilsson LN: The Arctic Alzheimer mutation facilitates early intraneuronal Abeta aggregation and senile plaque formation in transgenic mice. Neurobiol Aging 2006, 27:67-77.

26. Philipson O, Hammarström P, Nilsson KP, Portelius E, Olofsson T, Ingelsson M, Hyman BT, Blennow K, Lannfelt L, Kalimo H, Nilsson LN: A highly insoluble state of Abeta similar to that of Alzheimer's disease brain is found in Arctic APP transgenic mice. Neurobiol Aging 2009, 30:1393-1405

27. Codita A, Gumucio A, Lannfelt L, Gellerfors P, Winblad B, Mohammed AH, Nilsson LN: Impaired behavior of female tg-ArcSwe APP mice in the IntelliCage: A longitudinal study. Behav Brain Res 2010, 215:83-94.

28. Lord A, Englund H, Söderberg L, Tucker S, Clausen F, Hillered L, Gordon M, Morgan D, Lannfelt L, Pettersson FE, Nilsson LN: Amyloid-beta protofibril levels correlate with spatial learning in Arctic Alzheimer's disease transgenic mice. FEBS J 2009, 276:995-1006.

29. Ejarque-Ortiz A, Medina MG, Tusell JM, Perez-Gonzalez AP, Serratosa J, Saura J: Upregulation of CCAAT/enhancer binding protein beta in activated astrocytes and microglia. Glia 2007, 55:178-188.

30. Samuelsson M, Fisher L, Iverfeldt K: beta-Amyloid and interleukin-1 beta induce persistent NF-kappaB activation in rat primary glial cells. Int J Mol Med 2005, 16:449-453.

31. Ejarque-Ortiz A, Gresa-Arribas N, Straccia M, Mancera P, Sola C, Tusell JM, Serratosa J, Saura J: CCAAT/enhancer binding protein delta in microglial activation. J Neurosci Res 2010, 88:1113-1123.

32. Wu KK: Analysis of protein-DNA binding by streptavidin-agarose pulldown. Methods Mol Biol 2006, 338:281-290.

33. Ejarque-Ortiz A, Tusell JM, Serratosa J, Saura J: CCAAT/enhancer binding protein-alpha is down-regulated by toll-like receptor agonists in microglial cells. J Neurosci Res 2007, 85:985-993.

34. Duyckaerts C, Potier MC, Delatour B: Alzheimer disease models and human neuropathology: similarities and differences. Acta Neuropathol 2008, 115:5-38.

35. White JA, Manelli AM, Holmberg KH, Van Eldik L, Ladu MJ: Differential effects of oligomeric and fibrillar amyloid-beta 1-42 on astrocytemediated inflammation. Neurobiol Dis 2005, 18:459-465.

36. Jimenez S, Baglietto-Vargas D, Caballero C, Moreno-Gonzalez I, Torres M, Sanchez-Varo R, Ruano D, Vizuete M, Gutierrez A, Vitorica J: Inflammatory response in the hippocampus of PS1M146L/APP751SL mouse model of Alzheimer's disease: age-dependent switch in the microglial phenotype from alternative to classic. J Neurosci 2008, 28:11650-11661 
37. Johansson AS, Berglind-Dehlin F, Karlsson G, Edwards K, Gellerfors $P$, Lannfelt $L$ : Physiochemical characterization of the Alzheimer's diseaserelated peptides A beta 1-42Arctic and A beta 1-42wt. FEBS J 2006, 273:2618-2630.

38. Akira S, Kishimoto T: NF-IL6 and NF-kappa B in cytokine gene regulation. Adv Immunol 1997, 65:1-46.

39. Caivano M, Gorgoni B, Cohen P, Poli V: The induction of cyclooxygenase-2 mRNA in macrophages is biphasic and requires both CCAAT enhancerbinding protein beta (C/EBP beta ) and C/EBP delta transcription factors. J Biol Chem 2001, 276:48693-48701.

40. Prosch S, Heine AK, Volk HD, Kruger DH: CCAAT/enhancer-binding proteins alpha and beta negatively influence the capacity of tumor necrosis factor alpha to up-regulate the human cytomegalovirus IE1/2 enhancer/promoter by nuclear factor kappaB during monocyte differentiation. J Biol Chem 2001, 276:40712-40720.

41. Kowenz-Leutz E, Twamley G, Ansieau S, Leutz A: Novel mechanism of C/EBP beta (NF-M) transcriptional control: activation through derepression. Genes Dev 1994, 8:2781-2791.

42. Twamley-Stein G, Kowenz-Leutz E, Ansieau S, Leutz A: Regulation of C/EBP beta/NF-M activity by kinase oncogenes. Curr Top Microbiol Immunol 1996, 211:129-136

43. Nerlov C: The C/EBP family of transcription factors: a paradigm for interaction between gene expression and proliferation control. Trends Cell Biol 2007, 17:318-324.

44. Trautwein C, Caelles C, van der Geer P, Hunter T, Karin M, Chojkier M: Transactivation by NF-IL6/LAP is enhanced by phosphorylation of its activation domain. Nature 1993, 364:544-547.

45. Wegner M, Cao Z, Rosenfeld MG: Calcium-regulated phosphorylation within the leucine zipper of C/EBP beta. Science 1992, 256:370-373.

46. Kravchenko W, Mathison JC, Schwamborn K, Mercurio F, Ulevitch RJ: IKKi/ IKKepsilon plays a key role in integrating signals induced by proinflammatory stimuli. J Biol Chem 2003, 278:26612-26619.

47. Palsson EM, Popoff M, Thelestam M, O'Neill LA: Divergent roles for Ras and Rap in the activation of p38 mitogen-activated protein kinase by interleukin-1. J Biol Chem 2000, 275:7818-7825.

48. Clement JF, Meloche S, Servant MJ: The IKK-related kinases: from innate immunity to oncogenesis. Cell Res 2008, 18:889-899.

49. Liu YW, Chen CC, Tseng HP, Chang WC: Lipopolysaccharide-induced transcriptional activation of interleukin-10 is mediated by MAPK- and NF-kappaB-induced CCAAT/enhancer-binding protein delta in mouse macrophages. Cell Signal 2006, 18:1492-1500.

50. Savage MJ, Lin YG, Ciallella JR, Flood DG, Scott RW: Activation of c-Jun Nterminal kinase and p38 in an Alzheimer's disease model is associated with amyloid deposition. J Neurosci 2002, 22:3376-3385.

51. Dineley KT, Westerman M, Bui D, Bell K, Ashe KH, Sweatt JD: Beta-amyloid activates the mitogen-activated protein kinase cascade via hippocampal alpha7 nicotinic acetylcholine receptors: In vitro and in vivo mechanisms related to Alzheimer's disease. J Neurosci 2001, 21:4125-4133.

52. Taubenfeld SM, Wiig KA, Monti B, Dolan B, Pollonini G, Alberini CM: Fornixdependent induction of hippocampal CCAAT enhancer-binding protein [beta] and [delta] Co-localizes with phosphorylated cAMP response element-binding protein and accompanies long-term memory consolidation. J Neurosci 2001, 21:84-91.

53. Bradley MN, Zhou L, Smale ST: C/EBPbeta regulation in lipopolysaccharide-stimulated macrophages. Mol Cell Biol 2003, 23:4841-4858

54. Cardinaux JR, Magistretti PJ: Vasoactive intestinal peptide, pituitary adenylate cyclase-activating peptide, and noradrenaline induce the transcription factors CCAAT/enhancer binding protein (C/EBP)-beta and C/EBP delta in mouse cortical astrocytes: involvement in CAMPregulated glycogen metabolism. J Neurosci 1996, 16:919-929.

\section{doi:10.1186/1742-2094-8-34}

Cite this article as: Ramberg et al:: The CCAAT/enhancer binding protein (C/EBP) $\delta$ is differently regulated by fibrillar and oligomeric forms of the Alzheimer amyloid- $\beta$ peptide. Journal of Neuroinflammation 2011 8:34. 